\title{
Bending Capacity of Middle Joints of Upholstered Furniture Frames
}

\section{Moment savijanja T spojeva za ojastučeni namještaj}

\author{
Original scientific paper • Izvorni znanstveni rad \\ Received-prispjelo: 8. 2. 2012. \\ Accepted-prihvaćeno: 15. 11. 2012. \\ UDK: $630 * 836$; 630*824; 630*812.71 \\ doi:10.5552/drind.2012.1219
}

\begin{abstract}
This study evaluates the edgewise bending moment capacity of the four most frequently used middle joints in the upholstered furniture frames. The research included the following joints: Mortise and Tenon, double Dowel, Corner Blocks and double Gusset Plates, designed in the form of middle joints and made of beech and poplar solid wood. The test results indicated that regarding the edgewise bending force, the strongest middle joint was the double dowel joint made of beech wood $(1896.9 \mathrm{~N})$, while the respective joint made of poplar marked quite a low value of bending force (937.2 N). The strength of wooden corner blocks was proved to be quite powerful, made either of beech wood, poplar wood or the combination of the two wood species (beech: 1881.8 N, poplar: 1237.6 $\mathrm{N}$, beech-poplar: $1783.6 \mathrm{~N})$. The gusset plate joint made of beech resulted in weaker values (1378.2 N), compared to the dowel and corner block joints made of beech, whereas the same joint made of poplar demonstrated very satisfying values of edgewise bending force $(1471.8 \mathrm{~N})$. Finally, the mortise and tenon joint appeared to have the lowest strength, both in the case of beech (1306 N) and poplar $(634 \mathrm{~N})$. The highest coefficient of elasticity (CE) derived from double gusset plate joint, made of beech. All the joints showed good elasticity, except the mortise and tenon joint made of poplar, as well as, the dowel joint made of poplar, which recorded the lowest elasticity values of all. Generally, beech wood resulted in stronger and more elastic joints compared to poplar.
\end{abstract}

Key words: bending moment capacity, corner block joint, dowel joint, gusset plate joint, middle joint, mortise and tenon joint, upholstered furniture frame

\footnotetext{
SAŽETAK • U radu se prikazuje istraživanje momenta savijanja četiriju najčešće korištenih T sastava okvira ojastučenog namještaja. Istraživanje je obuhvatilo T spojeve okvira ojastučenog namještaja s čepom i rupom, dvostrukim moždanicima, drvenim kutnicima i dvostrukim drvenim pločicama. Uzorci su bili izrađeni od bukova i topolova drva. Rezultati ispitivanja pokazali su da je najjači spoj s obzirom na moment savijanja spoj okvira od bukovine s dvostrukim moždanicima $(1896,9 \mathrm{~N})$, dok je isti spoj od topolova drva imao prilično malu vrijednost momenta savijanja (937,2 N). Čvrstoća drvenog spoja izvedena drvenim kutnicima pokazala se vrlo dobrom bez obzira na to je li spoj izrađen od bukova ili topolova drva ili od kombinacije tih dviju vrste drva (bukovina: 1881,8 N, topolovina: 1237,6 N, kombinacija bukovina-topolovina: 1783,6 N). Spoj drvenim pločicama od bukovine pokazao je slabije vrijednosti $(1378,2 \mathrm{~N})$ od spoja dvostrukim moždanicima i spoja drvenim kutnicima od bukovine, dok je isti spoj od topolovine pokazao vrlo zadovoljavajuće vrijednosti momenta savijanja (1471,8 N). Konačno, spoj čepom i rupom pokazao je najslabije rezultate, kako u spoju od bukovine (1306 N), tako i u spoju od topolovine (634 N). Najviši koeficijent elastičnosti (CE) pokazao je spoj od bukovine s dvostrukim pločicama. Svi

${ }^{1}$ Authors are assistant and professor at Aristotle University of Thessaloniki, Faculty of Forestry and Natural Environment, Thessaloniki, Greece.

${ }^{1}$ Autori su asistent i profesor Fakulteta šumarstva i prirodnih resursa, Sveučilišta u Ateni, Atena, Grčka.
} 
spojevi rezultirali su sasvim zadovoljavajućim vrijednostima elastičnosti, osim spoja čepom i rupom od topolovine te spoja moždanicima od topolovine, koji je imao najniže vrijednosti elastičnosti od svih ispitivanih spojeva. Općenito, spojevi od bukovine pokazali su bolja svojstva čvrstoće i elastičnosti nego spojevi od topolovine.

Ključne riječi: moment savijanja, spoj drvenim kutnicima, spoj moždanicima, spoj drvenim pločicama, spoj čepom i rupom, okvir ojastučenog namještaja

\section{INTRODUCTION 1. UVOD}

The strength and stability of upholstered furniture mainly depend on the design of the frame pattern and the strength and stability of its joints (Eckelman 2003, Efe et al, 2005, Erdil et al, 2005 etc). Undoubtedly, there is a high interest in the research of the strength of the wooden frame and particularly the strength of the upholstered furniture joints.

The present research deals with the investigation of the edgewise bending moment capacity of the four basic and most frequently used middle joints of upholstered furniture, and namely: mortise and tenon joint, double dowel joint, wooden corner block joint and double gusset plate joint. The mortise and tenon joint and double dowel joint represent two main and traditional types of joints of upholstered and other sorts of furniture, and they have been already studied (Hill and Eckelman 1973, Paulenkova 1984, Smardzewski 2002, Tankut 2006, Zhang and Eckelman 1993, Efe et al, 2005), while the strength and the mechanical behavior of the other two types of joint presented in this research, the one with corner blocks and double gusset plates have not been thoroughly studied so far (Kazal et al. 2006, Erdil et al, 2003).

In this research, it was determined that the load was edgewise bending, because of the significance of the joint resistance to this type of load in the stability and resistance of the whole furniture frame. In the upholstered furniture, the middle joints are used to connect the front and back horizontal rails of the frame, a place where edgewise bending strength is the load that prevails and is therefore essential to test the joints with respect to this kind of load. The knowledge and understanding of the factors that affect the middle joint strength can be used in order to improve the joint design and hence the construction of the whole wooden frame of the furniture.

\section{MATERIALS AND METHODS 2. MATERIJALI I METODE}

Experiments were carried out with beech (Fagus silvatica L.) and poplar (Populus sp.), both of Greek origin and naturally dried for one year. The joints were constructed in the middle form (T-type) and their edgewise bending moment capacity was tested, and the corresponding coefficients of elasticity (CE) were also determined (in bending force). The specimens of double dowel and the mortise and tenon middle joints were only made of beech and poplar, while the other two joint types, the specimens of double corner block joint and double gusset plate joint, were not only made of beech and poplar, but also of a combination of the two wood species. Specifically, the third version of the double corner block joint was made of beech in the parts and poplar in the corner block joint of the specimens. Relatively to the double gusset plate joint, its third version was made of poplar in the parts and beech in the gusset plates of the specimen. The combination of these two wood species in corner blocks and gusset plates was to be tested because of its wide use (application) in the construction of upholstered furniture frames.

The dowels were made of beech wood, with the diameter of $12 \mathrm{~mm}$ and they had dapple surface. The adhesive used was Polyvinyl Acetate PVAc N203, durability class D3, with the density of $1.045 \mathrm{~g} / \mathrm{cm}^{3}, \mathrm{pH}$ $2.81,46.8 \%$ solid content after drying and viscosity of about $13,000 \mathrm{mPa} \cdot \mathrm{s}$ at $20{ }^{\circ} \mathrm{C}$ and $65 \%$ relative humidity. The staples were of Greek origin and construction, with the length of $4.5 \mathrm{~cm}$ for the connection of the two wooden elements and $3.5 \mathrm{~cm}$ for the assembly of corner blocks or gusset plates on the specimen.

All the specimens consisted of two horizontal wooden elements. The dimensions of the samples for testing the bending moment capacity were as follows: $150 \mathrm{~mm}$ length x $50 \mathrm{~mm}$ width x $25 \mathrm{~mm}$ thickness for element 1 , while the dimensions for element 2 were $125 \mathrm{~mm}$ length x $50 \mathrm{~mm}$ width x $25 \mathrm{~mm}$ thickness. The specimens dimensions of the current research have been specified based on commonly used dimensions in the construction of furniture frames, because of lack of particular international standards on the research method of the middle joint strength.

Concerning the double dowel joint, the dimensions of the dowel were: $40 \mathrm{~mm}$ length $\mathrm{x} 12 \mathrm{~mm}$ in diameter and the space between the two dowels was 13 $\mathrm{mm}$. In the construction of the mortise and tenon joint, the contact between the mortise and tenon was only to be maintained in the two surfaces of the mortise, because the mortise cut is semi-cylindrical, whereas the tenon has a square cut. In regard to the construction of the corner block joint, corner blocks with perpendicular sides of $30 \mathrm{~mm}$ were used. Also, each of the corner blocks was fixed by two staples. Regarding the construction of the double gusset plate joint, two wooden gusset plates were used alongside the connection place and each gusset plate was stabilized with the help of two staples (Figure1, D).

In the construction of the joints, pressure was not applied, except for those that included the use of staples (joint with corner blocks and joint with double gusset plates). 

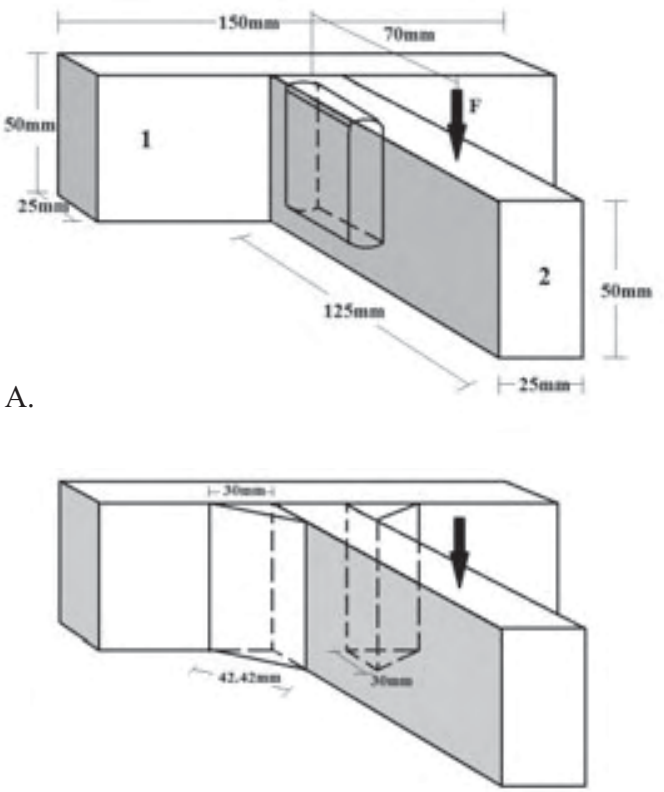

C.

Figure 1 Configuration of specimens and the way of application of edgewise bending load: A. mortise and tenon joint, B. double dowel joint, C. corner blocks, D. double gusset plates Slika 1. Oblik uzorka i smjer djelovanja sile opterećenja na savijanje: A. spoj čepom i rupom, B. dvostruki spoj moždanicima, C. spoj drvenim blokovima, D. spoj drvenim pločicama

For each joint, 10 specimens were tested. By using four types of joints, two wood species and a combination of the two species in two out of four joints, a total of 100 specimens were prepared. After their construction, the specimens were conditioned at the temperature of $20{ }^{\circ} \mathrm{C}$ and relative humidity of $65 \%$ and they were left there for three weeks to reach the nominal equilibrium moisture content (EMC) of $10 \%$. At the moment of the tests, the mean density of beech was $0.702 \mathrm{~g} / \mathrm{cm}^{3}$ and of poplar $0.364 \mathrm{~g} / \mathrm{cm}^{3}$, while the mean moisture content was $9.55 \%$ for beech and $9.29 \%$ for poplar.

The test was carried out on a Universal Testing Machine (SHIMADZU UH-300kNA) and the rate of crosshead-movement was adjusted to $8 \mathrm{~mm} / \mathrm{min}$, so that the maximum load was reached within $1.5 \pm 0.5 \mathrm{~min}$ throughout the test. The edgewise bending strength test of middle joints was performed using a specific device installed on the testing machine (Figure 2), in order to keep the element 1 of the specimen settled and leave the vertical part without support. The element 2 of the specimen was free to accept the pressure of the machine crosshead on its descent and the loading continued until the joint broke. At the end of this procedure, the maximum rupture load $(\mathrm{N})$ in edgewise bending moment capacity of the middle joints was recorded.

After the measurements, the bending moment capacity $(\mathrm{N} \cdot \mathrm{mm})$ and the coefficient of elasticity (CE) $\left(\mathrm{N} / \mathrm{mm}^{2}\right)$ of the middle joints were calculated, using the following equations:

$$
E=F \cdot S
$$

where $E$ is the bending moment capacity (N.mm), $F$ is the maximum rupture load $(\mathrm{N})$ and $S$ is the moment arm $(\mathrm{mm})$, which represents the distance measured

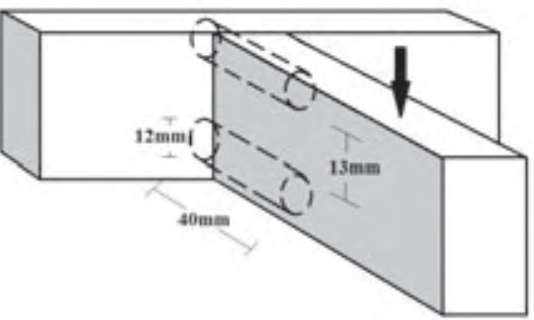

B.

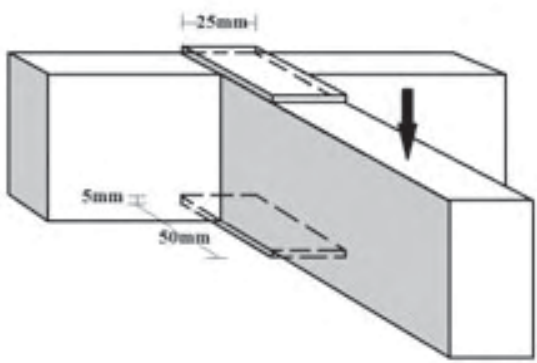

D.

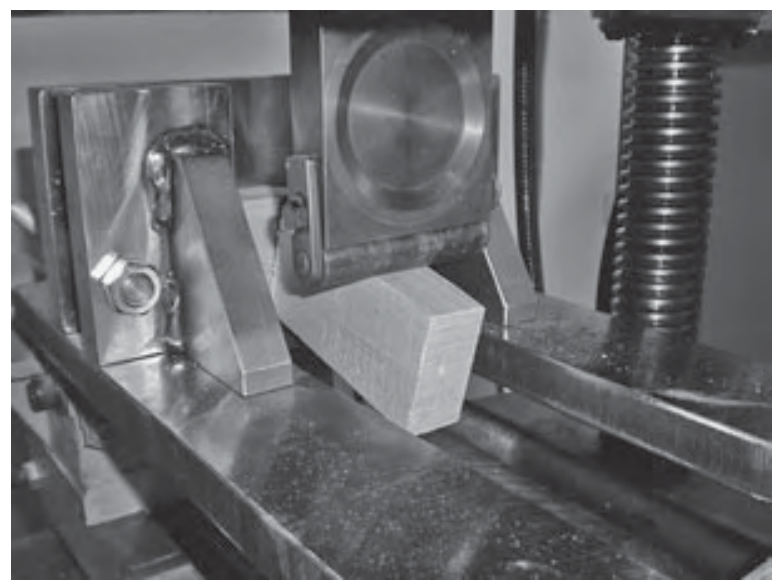

Figure 2 Device used for testing bending moment of middle joints

Slika 2. Uređaj za ispitivanje momenta savijanja drvenih spojeva

from the edge of element 2, till the point where the load is applied and in this research this length was $70 \mathrm{~mm}$ for all the specimens.

$$
C E=\frac{L \cdot S}{A \cdot D}
$$

where $C E$ is the coefficient of elasticity $\left(\mathrm{N} / \mathrm{mm}^{2}\right)$, $L$ is the load at the elastic limit (N), $S$ is the space between the two holding points of the joint (mm), $A$ is the area of the transverse cut surface $\left(\mathrm{mm}^{2}\right)$ and $D$ is the deformation at the elastic limit (mm).

For the statistical analysis of results, statistical software program SPSS PASW18 was used, and it was provided by the Aristotle University of Thessaloniki. Statistical analysis of covariance of the mean bending 
strength and elasticity values was carried out, using the Bonferoni and Tamhane method (one-way ANOVA).

\section{RESULTS AND DISCUSSION} 3. REZULTATI I RASPRAVA

The aim of this research was to investigate the edgewise bending moment capacity of middle joints, mainly because of high interest caused by the significance of this type of load for the wooden frame strength of the upholstered furniture. Middle joints that connect the basic parts of a furniture frame receive a range of different loads that also interact with one another, while the dominant load is undoubtedly the edgewise bending.

According to the above table, regarding the edgewise bending moment capacity, the middle joint of double dowel, made of beech, excelled greatly compared to all the other joints of the research, with maximum rupture load of $1896.9 \mathrm{~N}$ (moment capacity: 132783.6 N·mm). A little lower values were measured in the corner block joint, made of beech $(1881.8 \mathrm{~N})$ (moment capacity: $131726 \mathrm{~N} \cdot \mathrm{mm}$ ) and the same joint made of a combination of beech wood in the parts and poplar wood in the corner block 1783.6 N, (moment capacity $124852 \mathrm{~N} \cdot \mathrm{mm})$.

The one that followed, regarding the edgewise bending force capacity, was the double gusset plate joint made of poplar with $1471.8 \mathrm{~N}$ (moment capacity: $103026 \mathrm{~N} \cdot \mathrm{mm}$ ), while even lower strength values were given by the same joint made of beech, $1378.2 \mathrm{~N}$ (moment capacity: $96474 \mathrm{~N} \cdot \mathrm{mm}$ ). This fact leads to the conclusion that this specific joint (double gusset plates) made of poplar exhibits satisfying strength, especially when the main load in the construction is the edgewise bending (upholstered furniture frame for example). In an attempt to interpret and explain this strength superiority of double gusset plates made of poplar, compared to the corresponding beech joint, one could claim that poplar wood, having a different level of wettability, potentially created a successful adhesion line, given that the glued surface (between the plates and the specimen wooden elements) is quite large in this kind of joints. A little lower value $(1306 \mathrm{~N})$ was given by the mortise and tenon joint, made of beech (moment capacity: $91420 \mathrm{~N} \cdot \mathrm{mm}$ ) and the corner block joint made of poplar with $1237.6 \mathrm{~N}$ maximum rupture load (moment capacity: $86632 \mathrm{~N} \cdot \mathrm{mm}$ ).

Lower edgewise bending force $(942.4 \mathrm{~N})$ was demonstrated by the double gusset plate joint, made of a combination of two different wood species (poplar in the parts and beech in gussets) (moment capacity: 65968 $\mathrm{N} \cdot \mathrm{mm}$ ), while the strength value of the double dowel joint made of poplar ranged at the same level with 937.2 $\mathrm{N}$ (moment capacity: $65604 \mathrm{~N} \cdot \mathrm{mm}$ ). Among all the joints, the mortise and tenon joint made of poplar wood with $634 \mathrm{~N}$ (moment capacity: $44380 \mathrm{~N} \cdot \mathrm{mm}$ ) showed a very low bending force. The mortise and tenon joint is generally one of the most durable and stable joints, and it is recommended for use in constructions of solid wood. However in the case of this research, the double dowel joint seemed to be of much higher strength, while the mortise and tenon joint made of poplar showed the lowest strength of all the joints. This can be easily explained by the fact that the the mortise and tenon joint is designed in such a way that the tenon has a square cut, while the mortise has a semi-cylindrical cut, resulting in a reduced contact between the two wooden parts and a smaller gluing surface. Almost in all cases, with the exception of the double gusset plates, the joints made of poplar wood demonstrated much lower strength values compared to the respective joints made of beech wood and that is mainly attributed to the lower density of poplar wood. In a similar research, Efe et al. (2005) recorded a little higher edgewise bending force in the mortise and tenon as well as in double dowel middle joint, compared to the results of the present research, using three different wood species (beech, oak and pine), while Kazal et al (2006) found slightly lower edgewise bending strength in the corner block middle joint constructed with sweetgum and yellow-poplar wood.

According to the results of variance analysis, differences in groups were statistically significant with a

Table 1 Edgewise bending force and moment capacity of middle joints (mean values)

Tablica 1. Kapacitet sile i momenta savijanja drvenih spojeva

\begin{tabular}{|c|c|c|c|c|}
\hline $\begin{array}{l}\text { Joint type } \\
\text { Tip spoja }\end{array}$ & $\begin{array}{l}\text { Wood species } \\
\text { Vrsta drva }\end{array}$ & $\begin{array}{l}\text { Maximum } \\
\text { rupture load } \\
\text { Najveće } \\
\text { opterećenje } \\
\mathrm{N}\end{array}$ & $\begin{array}{c}\text { Bending moment } \\
\text { Moment savijanja } \\
\mathrm{N} \cdot \mathrm{mm}\end{array}$ & $\begin{array}{c}\text { Stand. } \\
\text { deviations } \\
\text { Standardna } \\
\text { devijacija }\end{array}$ \\
\hline \multirow{2}{*}{$\begin{array}{l}\text { Double dowel } \\
\text { dvostruki moždanici }\end{array}$} & Beech / bukovina & 1896.9 & 132783 & 7089.1 \\
\hline & Poplar / topolovina & 937.2 & 65604 & 6510.3 \\
\hline \multirow{2}{*}{$\begin{array}{l}\text { Mortise and tenon } \\
\text { čep s rupom }\end{array}$} & Beech / bukovina & 1306.0 & 91420 & 7421.9 \\
\hline & Poplar / topolovina & 634.0 & 44380 & 2055.1 \\
\hline \multirow{3}{*}{$\begin{array}{l}\text { Corner blocks } \\
\text { kutnici }\end{array}$} & Beech / bukovina & 1881.8 & 131726 & 8826.9 \\
\hline & Poplar / topolovina & 1237.6 & 86632 & 8241.0 \\
\hline & $\begin{array}{l}\text { Beech in the parts and Poplar in blocks } \\
\text { bukovina s topolovim kutnicima }\end{array}$ & 1783.6 & 124852 & 8628.1 \\
\hline \multirow{3}{*}{$\begin{array}{l}\text { Double gusset plates } \\
\text { dvostruke drvene } \\
\text { pločice }\end{array}$} & Beech / bukovina & 1378.2 & 96474 & 7124.7 \\
\hline & Poplar / topolovina & 1471.8 & 103026 & 6711.0 \\
\hline & $\begin{array}{l}\text { Poplar in the parts and Beech in plates } \\
\text { topolovina s bukovim pločicama }\end{array}$ & 942.4 & 65968 & 6428.0 \\
\hline
\end{tabular}




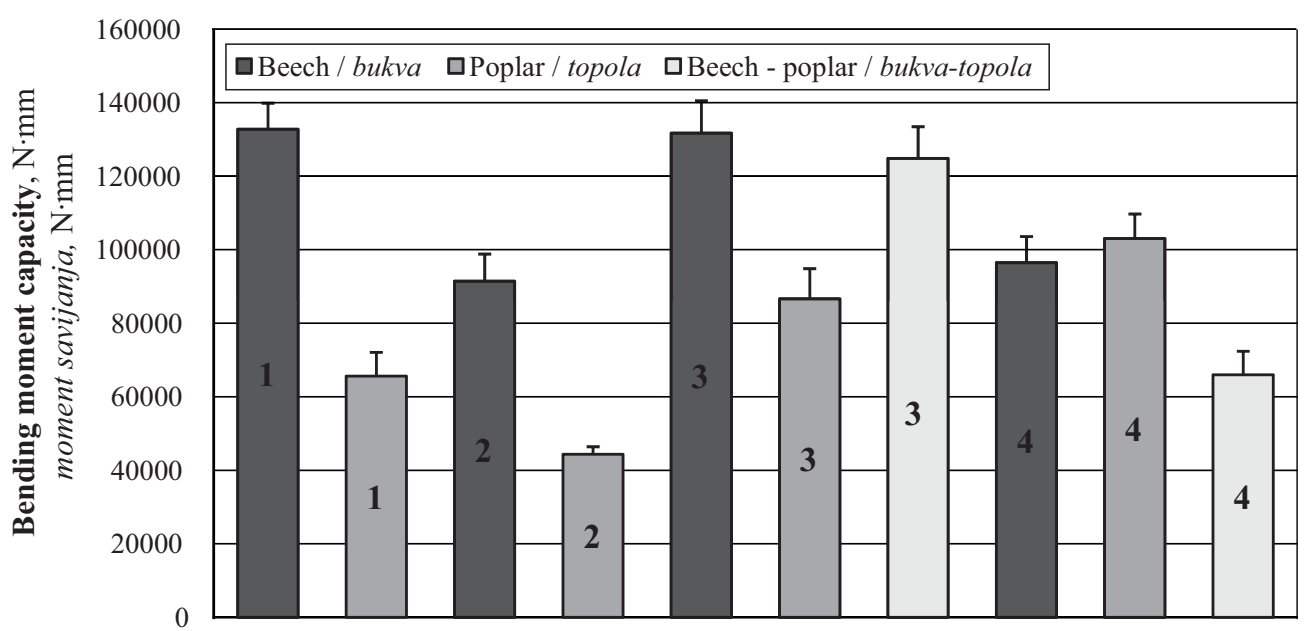

Joint type / vrsta spoja

Figure 3 Edgewise bending moment capacity of middle joints: 1. Double dowel joint, 2. mortise and tenon joint, 3. corner blocks, 4. double gusset plates

Slika 3. Vrijednosti momenta savijanja drvenih spojeva: A. dvostruki spoj moždanicima, B. spoj čepom i rupom, C. spoj drvenim kutnicima, D. spoj drvenim pločicama

$5 \%$ error. Statistically significant differences were recorded among all the joints, except for the following cases: double dowel joint made of beech wood gave similar values to the corner blocks made of beech wood and also to the corner blocks made of a combination of beech wood in the parts and poplar wood in the corner blocks. Furthermore, the strength value of the double dowel joint made of poplar wood did not differ significantly from the respective value of the gusset plate joint made of poplar in the parts and beech in plates. Additionally, similar values were determined for the mortise and tenon joint made of beech as well as for the corner blocks made of poplar wood, and the gusset plates, made either of beech or poplar wood. Also, similar strength seemed to have been obtained by the corner blocks made of poplar wood and the gusset plates made of beech wood. Finally, significant difference was not observed between the strength value of the gusset plates made of beech wood and the respective value of the same joint made of poplar wood.
The coefficient of elasticity $(C E)$ of each joint is calculated through the relation of the load that acts on the joint, with the simultaneous deformation caused by it. According to the results, the highest $C E$ values were measured in the double gusset plates made of beech $\left(37.5 \mathrm{~N} / \mathrm{mm}^{2}\right)$. The corner blocks made of a combination of beech in the parts and poplar in corner blocks followed with $33.2 \mathrm{~N} / \mathrm{mm}^{2} C E$ value, while a little lower $C E$ value was recorded with the same joint made of beech wood $\left(28.2 \mathrm{~N} / \mathrm{mm}^{2}\right)$.

Lower coefficient of elasticity in edgewise bending force was measured in the mortise and tenon joint made of beech wood with $C E$ value of $24.2 \mathrm{~N} / \mathrm{mm}^{2}$, and an even lower $C E$ was measured in the corner blocks made of poplar wood $\left(23.3 \mathrm{~N} / \mathrm{mm}^{2}\right)$. The double dowel joint made of beech wood appeared to have a little lower $C E$ value $\left(22.7 \mathrm{~N} / \mathrm{mm}^{2}\right)$. The elasticity value of the double gusset plates made of poplar was $21.2 \mathrm{~N} / \mathrm{mm}^{2}$, while the same joint made of a combination of poplar in the parts and beech in the plates followed with $19.7 \mathrm{~N} / \mathrm{mm}^{2}$.

Table 2 Coefficient of elasticity calculated in edgewise bending test (mean values)

Tablica 2. Koeficijent elastičnosti izračunan na temelju rezultata testa savijanja (srednje vrijednosti)

\begin{tabular}{|c|c|c|c|}
\hline $\begin{array}{l}\text { Joint type } \\
\text { Tip spoja }\end{array}$ & $\begin{array}{l}\text { Wood species } \\
\text { Vrsta drva }\end{array}$ & $\begin{array}{c}\text { Coefficient of elasticity } \\
\text { Koeficijent elastičnosti } \\
\mathrm{N} / \mathrm{mm}^{2}\end{array}$ & $\begin{array}{c}\text { Stand. deviations } \\
\text { Standardna } \\
\text { devijacija }\end{array}$ \\
\hline \multirow{2}{*}{$\begin{array}{l}\text { Double dowel } \\
\text { dvostruki moždanici }\end{array}$} & Beech / bukovina & 22.7 & 2.7 \\
\hline & Poplar / topolovina & 12.4 & 2.5 \\
\hline \multirow{2}{*}{$\begin{array}{l}\text { Mortise and tenon } \\
\text { čep s rupom }\end{array}$} & Beech / bukovina & 24.2 & 3.5 \\
\hline & Poplar / topolovina & 13.1 & 3.1 \\
\hline \multirow{3}{*}{$\begin{array}{l}\text { Corner block } \\
\text { kutnici }\end{array}$} & Beech / bukovina & 28.2 & 5.8 \\
\hline & Poplar / topolovina & 23.3 & 3.2 \\
\hline & $\begin{array}{l}\text { Beech in the parts and Poplar in blocks } \\
\text { bukovina s topolovim kutnicima }\end{array}$ & 33.2 & 5.7 \\
\hline \multirow{3}{*}{$\begin{array}{l}\text { Double gusset plates } \\
\text { dvostruke drvene pločice }\end{array}$} & Beech / bukovina & 37.5 & 5.7 \\
\hline & Poplar / topolovina & 21.2 & 4.0 \\
\hline & $\begin{array}{l}\text { Poplar in the parts and Beech in plates } \\
\text { topolovina s bukovim pločicama }\end{array}$ & 19.7 & 4.1 \\
\hline
\end{tabular}




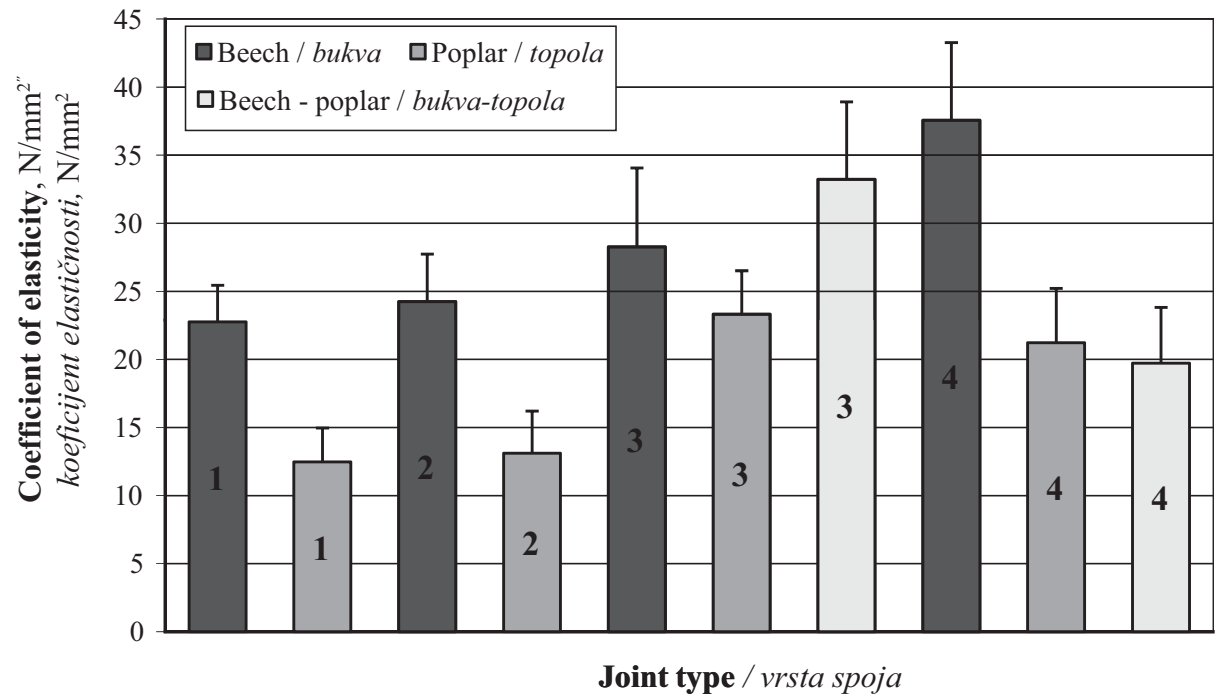

Figure 4 Coefficient of elasticity in edgewise bending strength of middle joints: 1. double dowel joint, 2. mortise and tenon joint, 3. corner blocks, 4. double gusset plates

Slika 4. Koeficijent elastičnosti savijanja drvenih spojeva: A. dvostruki spoj moždanicima, B. spoj čepom i rupom, C. spoj drvenim kutnicima, D. spoj drvenim pločicama

Finally, the mortise and tenon joint made of poplar had a much lower $\mathrm{CE}$ value $\left(13.1 \mathrm{~N} / \mathrm{mm}^{2}\right)$ and the double dowel joint made of poplar wood marked the lowest $C E$ value of all the joints in this research $\left(12.4 \mathrm{~N} / \mathrm{mm}^{2}\right)$. As can easily be noticed, all the joints in this research, made solely of poplar wood, demonstrated lower coefficient of elasticity values than the corresponding joints made of beech wood. It should also be noticed that the combination of two wood species in the case of double corner blocks proved to be quite effective both in edgewise bending moment capacity and the coefficient of elasticity, while the combination of two wood species in the case of gusset plates failed to give the expected bending force or $C E$ value.

According to the results of the variance analysis, statistically significant differences were observed between the following joints: the $C E$ value of the double dowel joint made of beech and also the mortise and tenon joint made of beech wood differed significantly from the dowel joint made of poplar, the mortise and tenon joint made of poplar wood, as well as the corner blocks made of a combination of the two species and the gusset plates made of beech wood. Furthermore, the double dowel joint made of poplar wood showed statistically significant differences from all the other joints of this study, except the mortise and tenon joint made of poplar wood. Finally, the coefficient of elasticity of all the versions of the corner block joint showed statistically significant differences from the corresponding value of all the versions of gusset plates, regardless of the material they were made of.

\section{CONCLUSIONS}

\section{ZAKLJUČCI}

This research evaluates the strength of the four most frequently used middle joints in the upholstered furniture frames: mortise and tenon, double dowel, corner blocks and double gusset plates. The joints were made of beech and poplar solid wood, in the form of middle joints and the edgewise bending strength of these joints was thoroughly investigated, as well as the coefficient of elasticity. Based on the results, the following conclusions can be drawn:

- The double dowel joint made of beech wood was proved to be the most durable joint of these four joints regarding the edgewise bending force, while the corner block joint made of beech and also made of a combination of two wood species (beech in the parts and poplar in corner block) resulted in a little lower strength values. Additionally, apart from the high value of the bending force, the corner block joint was proved to be characterized by quite a satisfying value of coefficient of elasticity.

- The double gusset plate joint made of poplar showed medium edgewise bending force, whereas the same joint made of beech resulted in even lower strength. Consequently, the gusset plates should be made of poplar, especially when the load that dominates in the structure is edgewise bending. Nevertheless, the specific joint indicated the highest coefficient of elasticity of all four joint types.

- The mortise and tenon joint was proved to be less durable in edgewise bending forces, especially when made of poplar. So, this particular joint did not provide the expected strength and also demonstrated among the lowest coefficients of elasticity.

- The lowest coefficient of elasticity in edgewise bending test was measured in the double dowel joint made of poplar wood.

- The combination of two wood species in the case of double corner block joint was proved to be quite effective both in edgewise bending force and in elasticity, while the combination of two wood species in the case of gusset plates failed to give either the expected bending force, or the elasticity value. 
- Finally, the joints made of beech proved to be characterized by higher values of edgewise bending force and coefficients of elasticity compared to the corresponding values of joints made of poplar.

\section{REFERENCES}

\section{LITERATURA}

1. Eckelman, C. A., 2003: Textbook of Product Engineering and Strength Design of Furniture. Chapter I. Introduction to Engineering Design.

2. Efe, H.; Zhang, J.; Erdil, Y.; Kasal, A., 2005: Moment capacity of traditional and alternative T-type end-to-side-grain furniture joints. Forest Products Journal, 55 (5): 69-73.

3. Erdil, Y. Z.; Zhang, J.; Eckelman, C. A., 2003: Staple holding strength of furniture frame joints constructed of plywood and oriented strandboard. Forest Products Journal, 53 (1): 70-75.

4. Erdil, Y. Z.; Kazal, A.; Eckelman, C. A., 2005: Bending moment capacity of rectangular mortise and tenon furniture joints. Forest Products Journal, 55 (12): 209-213.

5. Hill, M. D.; Eckelman, C. A., 1973: Furniture Engineering - Flexibility and bending strength of mortise and tenon joints. Furniture Design and Manufacturing. Vol. 45.

6. Kazal, A.; Erdil, Y. Z.; Eckelman, C. A., 2006: Shear force and bending moment capacities of joints constructed with glued corner blocks. Forest Product Journal, 56 (9): 74-79.
7. Paulenkova, M., 1984: Evaluation of the strength properties of mortise and tenon and dowel joints on cabinet bottom frames. Drevarsky Vyskum, 29 (2): 69-80. (in Slovak).

8. Smardzewski, J., 2002: Strength of profile-adhesive joints. Wood Science and Technology, 36 (2): 173-183. http://dx.doi.org/10.1007/s00226-001-0131-3.

9. Tankut, N., 2006: The effect of adhesive type and bond line thickness on the strength of mortise and tenon joints. International Journal of Adhesion \& Adhesives, 27 (6): 493-498 http://dx.doi.org/10.1016/j.ijadhadh.2006.07.003.

10. Zhang, J. L.; Eckelman, C. A., 1993: The bending moment resistance of single-dowel corner joints in case construction. Forest Products Journal, 43 (6): 19-24.

\section{Corresponding address:}

Assistant VASILIKI KAMPERIDOU, M.Sc.

Aristotle University of Thessaloniki

Faculty of Forestry and Natural Environment

Department of Harvesting and Forest Products

Technology

Thessaloniki, GREECE

e-mail: vkamperi@for.auth.gr 